\title{
The Meaning of Oko' Mama in Traditional Marriage
}

\author{
(Case Study in Tanini Village, Takari District, Kupang Regency, East Nusa Tenggara)
}

\author{
Feny Susana Eky*, Melki Tella, Merlin Luisa Malelak \\ Tourism Department \\ Kupang State Polytechnic \\ Kupang, Indonesia \\ *ekyfeny@gamil.com, melki_kabu@yahoo.co.id, merlinmalelak0305@gmail.com
}

\begin{abstract}
The purpose of this study is to analyse and get an overview of the meaning of $\mathrm{Oko}$ ' $\mathrm{Mama}$ in traditional marriage in Tanini Village, Takari District, Kupang Regency through the identification of the ideal of the traditional marriage tradition, the process of traditional marriage. This study uses qualitative research methods to analyse data obtained from the field. In determining the informants, the researcher used a purposive sampling technique and 5 people who were interviewed were used, consisting of traditional leaders, communities, religious leaders, and young people. To find out the meaning of $\mathrm{Oko}^{\prime}$ Mama in traditional marriage, so in this study, the qualitative research with a descriptive approach was used. The results of this study show that $\mathrm{Oko}$ 'Mama has several meanings in traditional marriage namely value of deliberation, value of religious tolerance, value of responsibility, value of cooperation, mutual value, value of justice, value of equality, and value of manners. However, the tradition of traditional marriage is gradually not being favoured by the younger generation, influenced by several factors, such as lack of interest and understanding of the traditional meaning of $\mathrm{Oko}^{\prime} \mathrm{Mama}$ in traditional marriage and ancient traditions, lack of local cultural education, and globalization. So, there are several efforts made to overcome this, namely with the efforts of the family, the efforts of the community and the efforts of educational institutions to support and encourage the younger generation to preserve and develop the tradition of Meaning $\mathrm{Oko}$ ' Mama in Traditional Marriage.
\end{abstract}

Keywords—traditional marriage, Oko’ Mama, Tanini village

\section{INTRODUCTION}

Tanini village is one of the villages in Takari District, Kupang Regency, East Nusa Tenggara. The Tanini people keep a variety of cultures or customs which become local wisdom of the local community. One of the cultures that exists in the Tanini community is Oko'Mama culture. In the context of marriage, traditional marriage is a marriage procedure that aims to strengthen back existing family relationships.

The decorations from Oko'Mama that are produced by each tribe have their own characteristics in the form of motifs that are around, as well as abstract forms. This tradition of the people of East Nusa Tenggara already exists in their ancestors which is then passed down from generation to generation. Most of the people of East Nusa Tenggara are still strongly adhering to the customs of their respective tribes. One of the tribes in East Nusa Tenggara who still adhere to cultural values as a legacy from their ancestors to date is the Timorese from Tanini Village, Takari District, Kupang Regency.

Among the Tanini community, Oko' Mama is not just a sign of appreciation for guests or something of value, but more than that Oko' Mama has social and customary functions. In addition, there are types of Oko' Mama that have certain motives that are not allowed to be worn by ordinary people but can only be worn by kings and descendants of kings or commonly known as Amaf or Usif.

The Oko' Mama culture is one of the many traditional products made in each area, one of which is the people of Tanini Village. According to the results of the observation found in Tanini Village, Takari District, there are various variations in the traditional Oko' Mama culture. The Oko' Mama process is still done traditionally but has its own meaning and value. In fact, by holding and using it as a traditional tool, it is as if we are navigating a sheet of historical documents from the community that made it, as a tradition that has been cultivated in the Tanini Village community from ancient times until now. The objectives to be achieved by researchers in the research carried out are to describe the meaning of Oko' Mama in traditional marriage for Timorese people in Tanini Village, Takari District, Kupang Regency.

\section{LITERATURE REVIEW}

In the culture of the Atoni Pah Meto (Atoin Meto) tribe, the tradition of chewing areca nut is called "mamat". The role of areca nut as a cultural symbol is very basic in the lives of indigenous people [1]. Oko' Mama (Oko' Mamat) is a rectangular box. Made from palm leaves. Its function is to store areca nut (betel, areca nut, lime betel and tobacco if any) [2]. When we call it Oko' Mama, it is certain that there is betel, areca nut, lime betel and/or tobacco. Oko’ Mama has become a habit for people living on the island of Timor. This has become a culture in everyday life. Every day, whether we meet them in social activities or in everyday life, cannot be separated from Oko' Mama, which is a container for storing betel and areca 
nuts [3]. Oko' Mama is a container or a place to store betel and areca nut. For Timorese people in general, the tradition of eating areca nut (chewing) is part of their life. Betel and areca nut is a cultural symbol that can be brought into the context of interpersonal communication, intra-cultural communication, ritual communication and political communication [4]. Every day, this habit continues to be carried out by residents. Before or after eating, during the day or at night, residents continuously do this activity. This habit is still carried out by the community throughout its life.

Oko' Mama is a tradition that has been around for a long time. It is not known exactly when this culture existed on the island of Timor. Oko' Mama is a tool or container that must be in every household. If we visit a neighbour's or relative's house, it is certain that Oko' Mama is there. Timorese say, "we eat betel first". Betel, areca nut and lime betel are placed in a square box, the Timorese call it Oko' Mama (Oko' Mamat). So Oko' Mama is synonymous with betel, areca nut and lime betel. A guest visiting someone else's house will first be treated with areca nut. This areca nut is placed in Oko' Mama. This box contains betel (manus), areca nut (puah), lime betel (ao) and tobacco (bako). But in everyday life, people only need to call it areca nut (puah manus). Everyone knows that if we call it areca nut, there must be betel, areca nut, lime betel and/or tobacco. Likewise, if people call it Oko' Mama, it is certain that in this container, there are chewing features.

Wedding or marriage is one of the most important religion and social cultural practices for almost all nations in the world [5]. Timorese traditional marriage is the love of a husband and a wife that requires sacrifice from both parties who love each other. There are several expressions, it is described how a man fights for his love to get the heart of his heart. The purpose of a traditional Timorese marriage is revealed through several expressions. The meaning of this expression is a prayer for offspring. Second, traditional marriage also aims to increase the closeness of the kinship between extended families. Third, marriage aims for the happiness of the married couple (male and female).

The customary law of marriage is a matter of kinship, family, fellowship, dignity, can forget personal matters depending on the composition of society [6]. Meanwhile, marriage in the sense of a customary agreement is a marriage that has a law against the customary law that applies in the community concerned. Marriage covers diverse aspects of the society as family and community relationships, sex and sexuality, inheritance, and even political power (as ruler ship particularly in the past resided in specific and designated families both the secular and the religious) [7]. It means that marriage and the rules of marriage cannot be separated in a society. Traditionally, wedding rituals have served three functions. These include: (1) serving as a transitional rite for an individual moving from one life stage to another (adolescent to adult, single to married), (2) providing reassurance that one is making the correct choice of partner and has approval of family and friends, and (3) uniting two families and fostering emotional bonds between family members [8]. Marriage is an agreement of both families to take any responsibilities together. Marriage is not only the events experienced by two different types of individuals. In fact, marriage is an event involving the burden and responsibility of family, relatives and even the testimony of community members [9].

Customs are all teachings about how people behave in society. The formula is so abstract that it requires some effort to fulfil and detail it further. Custom in this sense serves as the basis for the development of another positive customary law. Customs are needed by communities in their daily lives [10].

The definition of custom is basically "the provisions governing the behaviour of community members in aspects of human life". Therefore, custom is an unwritten law. In other words, customs are rules, habits that grow and are formed in a society that is considered to have values and is upheld and obeyed by the community. Therefore, custom regulates aspects of the life of community members, customary provisions also automatically regulate political or government issues, social economy, cultural ethics and so on. What is meant by customs in this research are habits in the form of material or nonmaterial being carried out by the community. Tanini Village as the work of the ancestors to be preserved.

\section{METHODS}

This research is a descriptive study which aims to describe the meaning and values of Oko' Mama in traditional marriage. The research was conducted in Tanini Village, Takari District, Kupang Regency. The data were taken from 5 informants who understand Oko' Mama in traditional marriage. The age of the informants in this research is around 30 years old up to 60 years old. Data collection techniques by means of observation, interviews, and documentation. Data analysis used the inductive model, in which the process of building hypothesis and drawing conclusion done based on the observation and data collection [11]. There are some points focused on this study such as the symbolic meaning of Oko' Mama in traditional marriage; the symbolic meaning of the shape of Oko' Mama; the symbolic meaning of the content of Oko' Mama.

\section{RESULTS AND DISCUSSION}

\section{A. Oko’ Mama Culture}

Oko' Mama in traditional marriage is a tradition, a tradition passed down from the ancestors of the Tanini community so that it is now cultivated and has become a habit for the Tanini people to keep this traditional marriage tradition so that it is not lost and swallowed up by the current globalization that is developing in this world. The Tanini people are still very strong in adhering to the culture and customs or habits of their ancestors, one of which is the Oko' Mama process. Because this traditional marriage process is identical with men and women. According to the Tanini community, the meaning of Oko' Mama in traditional marriage is one of the assets that is 
still maintained today to reflect its identity to the family or husband and wife.

\section{B. The Oko' Mama Culture Involved in the Traditional Timorese Wedding Ceremony}

Regarding values, the traditional Timorese wedding ceremony in the form of solidarity can describe several values that can be used as guidelines. In traditional wedding ceremonies there are negative values, but there are also positive values, including:

1) Value of deliberation: The Timorese people hold a democratic system in the structure of society, where there are customary councils as symbols of regulator, developer, and savior of customary values. Before making decisions for traditional wedding ceremonies, the Timorese people always prioritize deliberation between all families. To gather all families, the people of Timor use Oko' Mama as a medium for deliberation. The conversation took place after Oko' Mama was provided.

2) Value of brotherhood: In traditional wedding ceremonies, Oko' Mama is always used as a bonding medium for brotherhood, because with Oko' Mama, the siblings who are given feel are respected. Therefore, even though there is debate in deliberation, there is still a joint decision. Oko' Mama 's presence fosters a sense of brotherhood.

3) Value of religious tolerance: In traditional wedding ceremonies, of course the presence of guests of different religions cannot be avoided, but Oko' Mama is given to all guests without exception.

4) Value of equality. For atoin meto (Timorese): Oko' Mama is not only served for certain people or guest, but also for everyone in the wedding ceremony. Oko' Mama confirms that everyone is equal.

5) Value of responsibility: Oko' Mama is also a media to humbly ask someone to take a responsibility in the part of the wedding ceremony, for example kitchen matters (consumption), first the person is given Oko' Mama as a symbol of communication to who is fully responsible for the kitchen.

6) Value of mutual cooperation: Before holding mutual cooperation, a meeting is held first and always uses Oko' Mama as an effective communication tool. Oko' Mama for the Timorese is a sign of love and respect for themselves and others. The value of mutual cooperation in the traditional Timorese wedding ceremony is that the local community does not recognize social status in working together, and an example of strong mutual cooperation in traditional wedding ceremonies is mutual cooperation to prepare food.

7) Mutual value: Togetherness for the people of Timor is a value that is highly prioritized in traditional wedding ceremonies. In traditional marriage ceremonies, the values can be found in every process. The Timorese people have a sense of togetherness if they have been sitting down to eat areca nut or have been served with Oko' Mama. Their sense of togetherness is strongly tied because Oko' Mama has put them first as a sign of togetherness between individuals and other social groups.

8) Value of justice: The people of Tanini Village appreciate the value of justice because they always convey the value of justice with the Oko' Mama symbol. For the Timorese everything that exists must be shared equally and everyone has rights. This is reflected in the traditional wedding ceremony where when those invited do not attend the gathering (eating together), the family is obliged to provide food to be delivered to the house of those who are not present. This was done because the Timorese people thought that the invited guests who were not present also contributed to the traditional wedding ceremony.

9) Value of manners: The Tanini community has a high value of politeness because when people visit their house, before being served food and drink, they first hand over Oko' Mama . For the people of Tanini, Oko' Mama is a symbol of politeness, love and respect. At traditional wedding ceremonies, politeness is marked when presenting the betelfilled areca nut to guests with slow steps as if full of rhythm, and the third slightly bent body presents areca nut. The value of manners is also addressed in every traditional wedding ceremony, especially at the marriage ceremony where Oko' Mama is served to guests and families.

10) Oko' Mama 's cultural values: Culture has always presented something unique, because in general, culture is the work of humans who unwittingly become customs and even become a civilization. The people of Timor have a culture of Oko' Mama as a very important cultural value in Timorese society, therefore Oko' Mama must be maintained as a culture of high value. One of the cultures that is reflected in this traditional wedding ceremony is the culture or tradition of eating areca nut which is not only used for parents and elders but also for children.

\section{The Meaning of Oko' Mama in Traditional Marriage for the Tanini Community}

The Tanini people still maintain the Oko' Mama traditional marriage based on their daily needs and the customs of the Timorese people. Because in daily life the Tanini people cannot be separated by customs or culture because Oko' Mama is a symbol of Timorese love that must be embodied in the life of the Tanini people. The daily needs referred to in the results of interviews with several informants in the results of this study are daily needs in appreciating the guests who come in the daily life of the Tanini people. If they do not observe the custom of eating betel and areca nut, it means that the Tanini people do not respect traditional traditions. Every guest who comes to a Timorese house is always served areca nut first before being served food and drink. Likewise, in conveying a discussion or conversation, you must first eat betel, areca nut 
then enter the delivery of the aims and objectives. For the Timorese, Oko' Mama is the opening and closing of the road in conveying aims and objectives. The benefits of Oko' Mama make the Tanini people respect each other, creating a sense of brotherhood and a sense of togetherness.

The following are the meanings, values and functions of Oko' Mama in the life of Atoin Meto 'Timorese'. Functionally, Oko' Mama's culture contextually has universal meanings and values. These values come from the process of belief according to facts that do not need to be proven empirically. Value is a standard or measure of attitudes and behaviour that bind the community.

\section{1) The meaning of Oko' Mama's physical form}

- Oko' Mama is in the form of a rectangle, which means that social communication relations can be carried out from various directions from various social backgrounds regardless of social strata.

- Oko’ Mama has a pair of long wall planes and a pair of short wall planes, which means living in one wholeness and togetherness with other people despite different social status.

- Oko' Mama has an open upper room, which means being open to serving everyone and being open to receiving other people's ideas, as well as gifts from others.

- Oko’ Mama has a closed basement, which means a place to accommodate ideas, assets either own or obtained from others.

- The walls of Oko' Mama are decorated with various motifs, indicating the high level of civilization of atoin meto.

- Oko' Mamadianyam from palm leaves, shows the ability to manage and utilize natural resources.

- Oko' Mama consists of two parts, which means a symbol of the wholeness and togetherness of humans (male and female) in one family, also between guests and hosts or local people and immigrants, to create fraternal relations, togetherness and social balance.

- The contents of Oko' Mama are betel, areca nut, lime betel and tobacco, meaning symbols of individuals who are different but intact in togetherness and solid in unity, and complete in their respective existence.

2)The meaning of Oko' Mama's contents: In the biological dimension, the meaning of Oko' Mama's content is part of atoin meto's interdependence to their environment. Oko' Mama contains materials that are presented in the form of natural products obtained from the natural environment in which they live. The following is the meaning represented by the contents of Oko' Mama, namely:

- Manus 'betel' which symbolizes the man (husband, father) in charge of the family.
- Puah 'areca nut' as a symbol of the woman (wife, mother) of the next generation.

- Ao 'lime betel' as a symbol of fun and warm relationships between family members.

- Tobacco is a symbol of spirit or stimulus for family life in trying and interacting.

- The combination of lime and tobacco areca nut as a unifying symbol from various circles to produce something that is needed.

- The red colour is the result of eating betel as a symbol of the mutual reward of being full of courage and sincerity.

- If Oko' Mama contains money, then the meaning of money is a symbol of asking for permission or permission

The Oko' Mama culture reflects one's identity, outlook on life and social means that have existed for a long time. No one knows when this 'mama' (chewing) betel culture started. However, according to the atoin meto's traditional elders and leaders in Tanini Village, Takari District, Kupang Regency, the Oko' Mama culture is a legacy from atoin meto's ancestors. As one of the cultural symbols which is a symbol of friendship and social kinship in the community. The Oko' Mama culture has experienced a shift in the knowledge and understanding of values in atoin meto's younger generation. Various products from technological advances, mechanization, urbanization, industrialization, and the politicization of interests have led to the ignorance of the younger generation of Oko'Mama culture in terms of both form and meaning and function.

Atoin meto young people have begun to leave the mother's betel tradition by limiting it when they are in limited social activities, for example visiting relatives and at customary events and social activities, both attending girls' wedding ceremonies, weddings and even funerals. It is different from the older generation who do not limit the tradition of eating betel at every opportunity in their daily activities.

The substance of Oko' Mama culture lies not in the size of the treats or in the bargaining of the content of OkoMama in communicating and interacting, but in the effort to respect the dignity of humans and their civilization. So, the non-material value is more important when compared to the material value, here are the values contained in Oko' Mama for atoin meto:

- The attitude of always providing Oko’ Mama at home or anywhere has moral values, namely openness and courage.

- The attitude of always accepting other people by presenting areca nut has ethical values and cultural norms.

- Presenting areca nut with Oko' Mama has a measurement value and a dimension of the atoin meto's civilization existence. 
- Attitude by conveying the meaning by means of Oko' Mama has a value of responsibility in interacting, communicating and adapting.

- The attitude of starting a formal conversation with another person using Oko' Mama has a moral value of respect and respect.

- The attitude of presenting areca nut in the Oko' Mama container using the two ladders has the values of purity, sincerity, kinship and togetherness.

- The attitude of giving and accepting each other $O \mathrm{ko}^{\prime}$ Mama values solidarity, friendship, unity, pledge and promise.

- The attitude of presenting money in the Oko' Mama container has the value of fighting, respect for the dignity and dignity of others.

- The attitude of inviting people into the Oko' Mama culture contains values of desires and hopes.

- The attitude of rejecting the contents of Oko' Mama or accepting them without touching or taking the contents has the value of courage and knighthood.

The Oko' Mama culture is a legacy of atoin meto's ancestors, which is still relevant and dominates atoin meto's life and reflects the meto's identity from generation to generation. In fact, Oko' Mama culture still exists and functions as a means of social interaction, social approach, and kinship, controller, behaviour guide, social binder, community unifier or social unity, community peace maker, case breaker in society, revealed of people's hearts, liaison between people, appreciation and respect for others, reception, identity, a place to store betel, areca nut, lime betel and tobacco and social capital.

The meaning of Oko' Mama in religious terms is that the Tanini people interpret $\mathrm{Oko}^{\prime} \mathrm{Mama}$ as an intermediary to legalize customary marriages by channelling traditional traditions with the traditional Oko' Mama function because Oko' Mama in religious terms means uniting the groom and bride in a marriage tie custom in religion.

\section{CONCLUSIONS}

Based on the results of research conducted in Tanini Village, Takari District, Kupang Regency, it can be concluded as follows: The Meaning of Oko' Mama for the Tanini Community; a) Oko' Mama is also used in various ways such as in proposals, asking for requests, solving problems, politics and welcoming visitors to the village. b) Oko' Mama as a sociological meaning to facilitate dialogue and various information and thoughts. c) Oko' Mama as a means of media, purpose and a sign of excuse or a sign of respect to guests. It is recommended that the people of Tanini Village love local culture more because culture is the identity of an area. The people of Tanini Village can provide knowledge for the next generation about the importance of preserving local culture so that it is not swallowed up by the increasingly advanced currents of globalization because if a culture is lost, our regional identity will be lost. It is hoped that these young generations will be one of the big hopes in maintaining and preserving the local culture of the Tanini people because this is a cultural identity of their respective regions

\section{REFERENCES}

[1] E. Suminar, "Simbol dan Makna Sirih Pinang pada Suku Atoni Pah Meto di Timor Tengah Utara," Jurnal Komunikasi dan Bisinis, vol. 8 , no. $2,2013$.

[2] J.P. Ninu, "Oko' Mama dan politik praktis," Jurnal Ilmu-ilmu sosial Pluralis, vol. XI, no. 2, 2013.

[3] D. Tualaka, "Degradasi Fungsi, Makna dan Nilai Budaya Oko. Mama pada Komunitas Tutur Uab Meto," vol. 4, no. 1, 2018.

[4] E. Suminar, "Simbol dan Makna Sirih Pinang pada Suku Atoni Pah Meto di Timor Tengah Utara," Jurnal Komunikasi dan Bisinis, vol. 8, no. 2, 2013.

[5] R. Muhammad, M. Salehuddin, M. Zahari, A. Shuhaida, M. Ramly, and R. Ahmad, "The Roles and Symbolism of Foods in Malay Wedding Ceremony," Procedia - Social and Behavioral Sciences 101, 2013.

[6] Welem, Sosiologi Agama, Jakarta: Pustaka Pelajar. 2004

[7] B. Ubong, "Traditional Marriage Ceremonies Among the Ibibio People of Nigeria: A Study in Theatrics," Venets: The Belogradchik Journal For Local History, Cultural Heritage And Folk Studies, vol. 1, no. 3, 2010.

[8] M.W. Barnes, "Our Family Functions: Functions of Traditional Weddings for Modern Brides and Postmodern Families," John Carroll University Carroll Collected Sociology, 2014.

[9] W. Sinaga and R. Damanik, "Symbols, Functions and the Meaning of Wedding Clothes in Implanting Simalungun Cultural Values," International Journal of Research and Review, vol. 7, 2020.

[10] Koentjaranigrat. Pengantar Antropologi, Jakarta: Rineka Cipta. 1980

[11] L. Moleong, Metodologi Penelitian Kualitatif, Bandung: Remaja Rosdakarya. 2014. 